\title{
Specify KIT Mutation
}

National Cancer Institute

\section{Source}

National Cancer Institute. Specify KIT Mutation. NCI Thesaurus. Code C160579.

A request to enter the specific KIT mutations that were identified in the study. 